\title{
Corpo-infância - exercícios tensos de ser criança; por outras pedagogias dos corpos de Miguel G. Arroyo e Maurício Roberto da Silva (Orgs.).
}

\author{
Petrópolis, RJ: Vozes, 2012. \\ Renata Cocato Costa \\ Graduada em Pedagogia (Uninove) e em Ciência da Computação (Uninove); \\ Mestranda em Gestão e Práticas Educacionais (PROGEPE - Uninove); \\ Professora de Educação Infantil da Prefeitura do Município de São Paulo \\ São Paulo, SP - Brasil. \\ re.cocato@gmail.com
}

Uso as palavras para compor meus silêncios. Não gosto das palavras fatigadas de informar.

Dou mais respeito às que vivem de barriga no chão tipo água pedra sapo

Manoel de Barros

Miguel Gonzáles Arroyo é professor titular emérito da Faculdade de Educação da Universidade Federal de Minas Gerais (UFMG) e autor de diversas obras na área da educação; Maurício Roberto da Silva é Doutor em Ciências Sociais Aplicadas à Educação pela UNICAMP, com Pós-doutoramento em Estudos da Criança na Universidade do Minho (Portugal), e autor de livros como Trama doce-amarga - (Exploração do) trabalbo infantil e cultura lúdica. Juntos, organizaram textos de vários autores e publicaram, em 2012, o livro objeto desta resenha, uma coletânea de estudos e vivências que poderão contribuir para ampliar a visão sobre a relação criança/sociedade e sobre a relevância da corporeidade neste contexto.

O livro está dividido em quatro partes, nas quais os autores discutem situações de precarização do corpo. Trata-se de experiências vivenciadas nos mais variados contextos de "minorias inferiorizadas" que a história da educação e da infância invisibilizaram, retratos de antipedagogias que não constam do currículo e que são reveladas, em suas dimensões política, pedagógica e cultural, no decorrer dos capítulos.

$\mathrm{Na}$ Parte I, o foco é dado aos corpos precarizados, merecedores de reconhecimento, "coletivos" que ainda hoje são desprezados e que possuem uma necessidade de se reconhecerem e de serem reconhecidos enquanto indivíduo e sujeito-social 
de valor. Em texto de sua autoria, Miguel Arroyo considera que o desprezo desses coletivos leva, muitas vezes, a um contexto de violência no ambiente escolar, um reflexo da brutalidade que perpassa suas vivências desde o nascimento, desde a gestação, num ato até inconsciente de busca de sua identidade, de seu lugar ao sol. Essa imagem constituída de violência gera práticas que os exclui ainda mais, chegando a uma condição sub-humana. Durante todo o texto o leitor é instigado a um estudo profundo das realidades e vivências ocultadas socialmente, num movimento que clama por mudanças nos currículos escolares, currículo este que tem urgência em "[. . . ] superar visões negativas, segregadoras e inferiorizantes e avançar para miradas mais compreensivas, mais positivas seria uma rica contribuição dos estudos da infância." (p. 28)

O texto das pesquisadoras Maria dos Anjos Lopes Viella e Célia Regina Vendramini mostra que essa visão negativa tem como principal vítima a corporeidade, na medida em que práticas corporais são massacradas por ações rotineiras exageradas, excessivo controle, várias horas de estudo, silêncio em relação à sexualidade. É no corpo que se imprimem as marcas sociais, e a busca da libertação corpórea faz com que as autoras percorram e analisem quais são os corpos precarizados.

Em artigo resultante de uma pesquisa de campo, Jaciara Oliveira Leite e Ana Márcia Silva trazem o conceito de abrigo, caracterizando-o como o espaço em que a criança pode romper com a realidade e ter um lugar de proteção; trazem também os corpos precarizados pelo trabalho infantil em atividades ilícitas dentre elas a exploração comercial da sexualidade de crianças e adolescentes - e uma crítica à pedagogia que desconsidera e oculta tais sujeitos.

A Parte II fala dos corpos resistentes, relatando a experiência de um grupo de professores de Pedagogia e Educação Física no meio rural, como Paulo Ricardo do Canto Capela e Edgard Matiello Júnior, no contexto de um assentamento do Movimento Sem Terra - MST. Nessa vivência, percebe-se a necessidade de um currículo aberto, que esteja em movimento, que seja inacabado, que valorize a infância; não a infância do "vir a ser", mas a do hoje. Como desafio, os professores tiveram que tornar o conhecimento mais significativo, e o meio mais eficaz foi o trabalho com projetos, pelo qual o conhecimento se constrói de forma integral e no qual todos os envolvidos se percebem enquanto pesquisadores, além de se processar numa relação de aprendizagem com a realidade, com a vida. Durante 
o projeto, observa-se um resgate da cultura corporal das crianças pelo uso das múltiplas linguagens.

O contexto cultural indígena é enfatizado no texto de Luciano Silveira Coelho e José Alfredo Oliveira Debortoli, no qual os autores mostram como, para os indígenas, conhecimento, prática e vida são indissociáveis. Há uma postura diferenciada em que os adultos são uma referência para os mais jovens, dispondo de seu tempo para ensinar, participar, envolver ou apenas observar as crianças em suas práticas cotidianas, de tal forma que, gradualmente, crianças e jovens aprendem a se inserir em distintos modos de participação na comunidade, processo de suma importância para a constituição de sua identidade.

O livro também traz, em artigo do pesquisador Valmir Luiz Stropasolas, a visão negativa do meio rural. Como contraponto a tal visão, o autor postula um currículo pensado a partir do contexto das populações rurais, num compartilhamento escola/famílias que redunde em aprimoramento das práticas de aprendizagem, na forma de uma educação cidadã, na busca dos direitos para as pessoas do campo, na ampliação de recursos e oportunidades. Para isso, aproximar-se da realidade cultural desse contingente, no sentido de valoriza-la e promove-la, fortalece a cidadania e a identidade do morador das áreas rurais.

O último artigo da Parte II retrata as vivências e brincadeiras das crianças de uma comunidade quilombola, sua expressividade, criatividade, originalidade e pertença ao território em que vivem, a partir de uma pesquisa de doutorado de Elaine de Paula, feita sob orientação do professor João Josué da Silva Filho.

A Parte III volta-se para os ambientes educativos, numa análise dos corposinfância dos sujeitos da educação, remetendo a uma análise dos tempos-espaços do cotidiano da Educação Infantil, das relações com o corpo e da percepção de como se dá a aquisição da cultura corporal nesse espaço, como bem se descreve no artigo de Maurício Roberto da Silva. Avaliam os autores que esses tempos-espaços tanto podem ser repressivos quanto emancipadores. Na perspectiva emancipatória, trata-se de garantir uma formação integral (linguística, intelectual, expressiva, emocional, corporal, social e cultural), com base numa formação sólida dos professores.

Sobre a concepção e prática da formação integral, a autora Ângela Maria Scalabin Coutinho foca a Educação Infantil em creches, porém, com o olhar da Sociologia da Infância, em decorrência de suas vivências práticas nessas instituições, numa luta por mais respeito à infância e pela mudança de postura dos professores. 
Os professores não devem ser coniventes com a reprodução de uma infância invisibilizada pelos adultos que não lhe dão voz e não as reconhecem enquanto sujeito de direitos. Em razão disso, a autora Márcia Buss-Simão expõe a necessidade de criação de espaços de participação infantil, entendidos como de efetiva ação das crianças nas decisões e ações referentes àquilo que é de seu interesse. Nesse contexto, cabe a nós professores refletir sobre nossas ações, passar a ouvir e olhar mais as infâncias e construir práticas também a partir de suas perspectivas.

Perspectivas que as autoras Adriana de Castro Fonseca e Eliete do Carmo Garcia Verbena e Faria trazem no livro como proposta curricular, apresentando novas possibilidades de intervenção do professor nas quais se contempla a visão social e cultural das infâncias.

Por fim, a Parte IV inicia com uma reflexão sobre o papel da mídia e sua influência na conformação de uma cultura da infância. Os estudos realizados pelos autores: Ingrid Dittrich Wiggers, Iracema Munarim, Gilka Elvira Ponzi Girardello e Rogério Santos Pereira traçam uma crítica baseada nas representações das crianças sobre os estereótipos difundidos pela mídia, entre eles a excessiva valorização do padrão europeu, entendendo que os meios de comunicação têm um poder avassalador sobre as massas populares. Surge, então, a grande questão: Como usufruir desses veículos de forma crítica, não alienante? Os autores também propõem uma reflexão sobre as relações da criança com a educação, sobre as formas como elas vêm assimilando as transformações do mundo em seu processo de avançada mercantilização. Pregam uma discussão sobre as infâncias, o brincar, os brinquedos, o corpo e o movimento do universo infantil, partindo de perspectivas múltiplas.

A leitura do livro favorece um pensar sobre a prática pedagógica de uma perspectiva emancipatória, com análise cuidadosa dos tempos e espaços que são oportunizados às infâncias, da importância da imaginação e do brincar, do desenvolvimento do corpo em suas mais variadas formas de expressão, do quão significativas são as vivências. Acentuam que tais vivências devem ser coerentes com a realidade social em que as infâncias estão inseridas, de modo a valorizar as culturas infantis em seus mais diversificados contextos.

Para concluir, cabe reproduzir uma citação extraída do artigo dos organizadores do volume: "Nada fácil para profissionais que nos ensinaram a ensinar mantendo os aprendizes em silêncio. Como superar essas didáticas para entender e valorizar as duras linguagens de suas vidas-corpos tão falantes e tão denunciantes? (p. 48-9). 